\title{
Refsum's Disease: Characterization of the Enzyme Defect in Cell Culture
}

\author{
James H. Herndon, Jr., Daniel Steinberg, B. Whlitam UhLendorf, and \\ HenRy M. Fales \\ From the Molecular Disease Branch, National Heart Institute and the \\ Laboratory of Viral Immunology, Division of Biologics Standards, National \\ Institutes of Health, Bethesda, Maryland 20014
}

A в S T R A C T Refsum's disease (heredopathia atactica polyneuritiformis, HAP) is an inherited neurological disorder associated with storage of the branched-chain fatty acid, phytanic acid (3,7,11,15-tetramethylhexadecanoic acid). Cultured fibroblasts derived from skin biopsies of HAP patients did not contain elevated levels of phytanate, yet showed rates of phytanate- $\mathrm{C}-{ }^{14} \mathrm{C}$ oxidation less than $3 \%$ of those seen in cells from control subjects. Cells of control subjects converted phytanate to $\alpha$-hydroxyphytanate, to pristanate (the [n-1] homologue of phytanate) and to 4,8,12-trimethyltridecanoate, compounds previously identified as intermediates on the major pathway for phytanate metabolism in animals, providing the first direct evidence that this same oxidative pathway is operative in human cells. None of these breakdown products could be found after incubation of phytanate with HAP cells. Labeled $\alpha$-hydroxyphytanate and labeled pristanate were oxidized at normal rates by HAP cells. Oxidation of the latter proceeded at normal rates both when added to the medium at very low tracer levels and at levels 100 times greater. Phytanate was incorporated into and released from lipid esters at normal rates by HAP cells. Elevated levels of free phytanate in the medium were no more toxic to HAP cells than to control cells over the 48- to 72 -hr exposures involved in these studies, as evidenced by morphologic criteria and by ability to oxidize labeled palmitate. These findings are consistent with the hypothesis that the cells from HAP patients are deficient in a single enzyme involved in the $\alpha$-hydroxylation of

Dr. Herndon's address is Section of Dermatology, Department of Medicine, Yale University School of Medicine, New Haven, Conn. 06510. Dr. Steinberg's address is Division of Metabolic Disease, Department of Medicine, University of California, San Diego, La Jolla, Calif. 92037.

Received for publication 1 November 1968 and in revised form 3 February 1969. phytanate, while the enzymes involved in later steps are present at normal or near-normal levels.

\section{INTRODUCTION}

Heredopathia atactica polyneuritiformis (HAP) was defined as a clinical entity by Refsum in 1946 (1). Constant features of the syndrome include retinitis pigmentosa, peripheral polyneuropathy, cerebellar ataxia, and elevated cerebrospinal fluid protein without pleocytosis. Cardiac conduction abnormalities, pupillary changes, nerve deafness, anosmia, ichthyosis, and bony abnormalities occur in a large proportion of cases (2). An autosomal recessive pattern of inheritance was proposed by Refsum, and additional genetic data support this (3). In 1963, Klenk and Kahlke showed that the syndrome was associated with accumulation of phytanic acid (3,7,11,15-tetramethylhexadecanoic acid) in blood and tissues (4). Studies by Steinberg and coworkers (5-8) have shown that phytanic acid is not synthesized endogenously but originates in the diet and that the patients with HAP have a defect in the oxidative pathway for degradation of phytanic acid. With the recent elucidation of a major pathway for phytanic acid oxidation in animals (9-11), it became possible to further localize the defect by testing the ability of patients to oxidize metabolic products of phytanate.

The results presented below show that the enzyme defect in phytanic acid oxidation persists in fibroblast cultures derived from the skin of patients with HAP. Data are presented showing that the alpha-oxidative pathway for phytanate oxidation established by animal studies is present also in human tissues, the first degradation products being $\alpha$-hydroxyphytanic acid and pristanic acid (2,6,10,14-tetramethylpentadecanoic acid). Finally, it is shown that the rate of oxidation of pristanic acid 
and of $\alpha$-hydroxyphytanic acid is unimpaired in the patients' cultured cells, indicating that the principal enzyme defect lies in the production of $\alpha$-hydroxyphytanic acid, presumably the first step in phytanic acid oxidation. Preliminary reports of some of these findings have appeared (12-14).

\section{METHODS}

Sources and preparation of labeled compounds. Phytol$\mathrm{U}-{ }^{14} \mathrm{C}$ was purified as previously described (15) from the nonsaponifiable lipid fraction of algae grown in ${ }^{11} \mathrm{CO}_{2}$. After addition of carrier phytol, radiopurity was checked by thinlayer chromatography (TLC) of phytol itself, TLC after derivative formation (aldehyde and acetyl ester), and by radioassay of fractions collected from a gas-liquid chromatography (GLC) column (16) (17\% ethylene glycol succinate [EGS] on Chromosorb W, Applied Science Laboratories Inc., State College, $\mathrm{Pa}$.).

Phytanic acid-U- ${ }^{14} \mathrm{C}$ was prepared from labeled phytol either as described in detail previously (15) or by the following procedure: phytol- $\mathrm{U}-{ }^{11} \mathrm{C}$ was reduced to dihydrophytol-U ${ }^{14} \mathrm{C}$ by hydrogenation with platinum oxide in ethanol. ${ }^{1}$ The dihydrophytol-U- ${ }^{14} \mathrm{C}$ was then oxidized to phytanic acid$\mathrm{U}-{ }^{14} \mathrm{C}$ with chromic acid in glacial acetic acid $(2 \mathrm{hr})$. Purity of the phytanic acid $(>95 \%)$ was confirmed by cochromatography of its methyl ester with authentic methyl phytanate on several GLC liquid phases and by gas-liquid radiochromatography (16). Unless otherwise stated, radiopurity of each of the labeled compounds used was similarly confirmed by gas-liquid radiochromatography.

Pristanic acid-U-" C was prepared from phytanic acid$\mathrm{U}-{ }^{10} \mathrm{C}$ by a Barbier-Wieland degradation and purified by thin-layer and gas-liquid chromatography (9). Homophytanic acid-U ${ }^{14} \mathrm{C}$ was prepared from labeled phytanic acid by the Arndt-Eistert procedure-treatment of phytanoyl chloride with ethereal diazomethane and rearrangement of the diazoketone with a methanolic suspension of silver oxide. Radiopurity of both pristanic and homophytanic acids was over $95 \%$.

\footnotetext{
${ }^{1}$ For reasons which remain obscure, some batches of $\mathrm{PtO}_{2}$ were associated with extensive hydrogenolysis and low vields of the reduced compound.
}

$\alpha$-hydroxyphytanic acid-U- $-{ }^{14} \mathrm{C}$ was prepared from phytanic acid-U- ${ }^{14} \mathrm{C}$ by bromination and hydrolysis in aqueous methanol. The product after methylation behaved as a single component on GLC and its mass spectrum, determined using the LKB-9000 combined GLC-mass spectrometer, was characteristic for the methyl ester of an $\alpha$-hydroxy acid (17). On the other hand, two distinct bands were resolved by TLC (ethyl acetate-hexane, $10: 90 ; R_{\mathrm{f}}$ values, 0.38 and 0.33 ). The hydroxyphytanate radioactivity was equally divided between the two bands (upper band, $51 \%$; lower band $49 \%$ ). Actually four stereoisomeric compounds are expected in the synthesis of $\alpha$-hydroxyphytanate from phytol (see Fig. 1). Natural phytol (from chlorophyll) has been shown $(18,19)$ to have the $\mathbf{D}$ configuration at carbon-7 and -11 . The absolute configuration was shown by Kates et al. (20) to be R. No changes at these two asymmetric centers should occur during the synthesis from phytol, and their designation is omitted in the following discussion. Reduction of the 2,3-double bond of phytol (followed by oxidation of the alcohol function) should give equal amounts or 3-D- and 3-L-phytanic acid. Each of these then gives rise to equal amounts of 2 -D-hydroxy and 2-L-hydroxy acid. Thus the four $\alpha$-hydroxyphytanate species expected are: (2-D, 3-D), (2-D, 3-L), (2-L, $3-D)$, and (2-L, 3-L). Separation by TLC into two bands can be best explained on the basis of interactions between the 2-hydroxyl and the 3-methyl groups affecting polarity. Thus one band might be expected to contain (2-D, 3-L) plus (2-L, $3-D)$, while the other would contain (2-D, 3-D) plus (2-L, $3-L$ ). Resolution of the latter pair certainly would not be anticipated. In confirmation of this interpretation, the optical rotations of both bands at $589 \mathrm{~m} \mu$ were essentially zero. Neither band exhibited a true Cotton effect from 250 to 217 $\mathrm{m} \mu$, but the lower band showed $(\alpha)_{200^{\circ}}=+195^{\circ} \pm 20^{\circ}$ and a sudden sharp rise before extinction at $215 \mathrm{~m} \mu$. The upper zone was very weakly positive at the same wavelength $(\alpha)_{220}{ }^{\circ}=+52^{\circ} \pm 30^{\circ}$. Additional confirmation of the nature of the two bands was obtained through the hydroxylation of 3D, 7D, 11D phytanic acid kindly supplied by Dr. M. Kates. This material was converted to its 2 -hydroxy derivative and separated as the methyl ester into two bands on TLC identical in $R_{\mathfrak{f}}$ with those obtained from the (3-D, 3-L) mixture. Each zone exhibited the same mass spectral pattern; as expected with diastereoisomers, and they may be tentatively assigned the 2D, 3D, 7D, 11D and 2L, 3D, 7D, 11D configurations. Insufficient material was available for optical rotation studies.

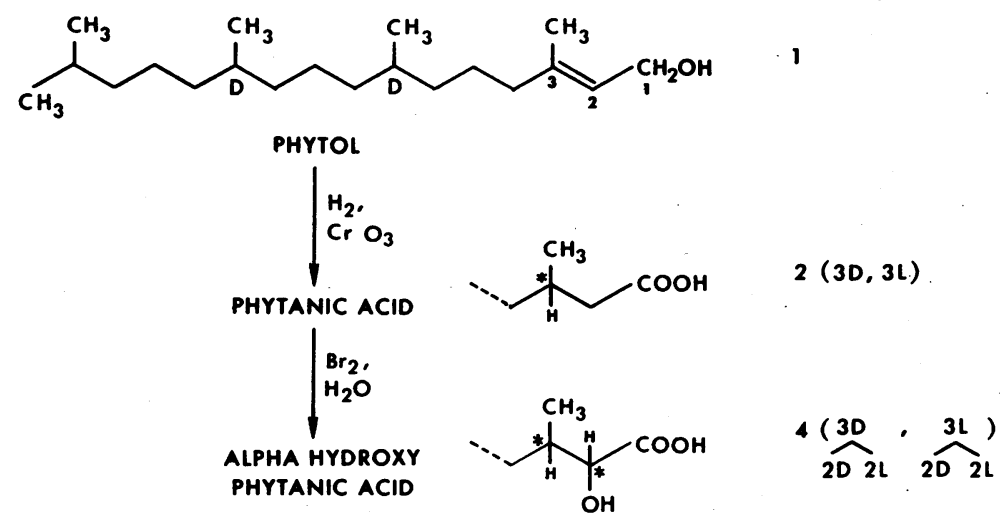

FIGURE 1 Formation of four isomeric forms of $\alpha$-hydroxyphytanic acid in the chemical synthesis from natural phytol (from chlorophyll). 
The labeled $\alpha$-hydroxyphytanate mixtures in the upper and lower TLC bands were used separately as substrates in the tissue culture system, testing for differences between reference cultures and HAP cultures. In the absence of determination of absolute configuration, they are arbitrarily designated "less polar isomers" and "more polar isomers," respectively.

Palmitic acid-9, $10-{ }^{3} \mathrm{H}$ and palmitic acid-1 $-{ }^{14} \mathrm{C}$ were purchased from the New England Nuclear Corp., Boston, Mass. These and all other radioactive fatty acids, with the exception of $\alpha$-hydroxyphytanate, were purified by GLC of methyl esters before use, as previously described (15). After hydrolysis of the methyl esters, labeled free acids were converted to potassium soaps with $\mathrm{KOH}$ and added to a swirling aqueous solution containing albumin. The amounts of fatty acid used did not exceed the binding capacity of the albumin present, and all solutions were clear when added to the tissue culture media. The methyl ester of $\alpha$-hydroxyphytanic acid-U- ${ }^{14} \mathrm{C}$ was purified by TLC as described above. Trimethyl silyl ethers were prepared (21) from the eluted $\alpha$-hydroxyphytanate isomers and subjected to analytical GLC (17\% EGS on Chromosorb W) with collection of fractions for radio-assay (16). Radiopurity greater than $93 \%$ was demonstrated. GLC of the nonsilylated $\alpha$-hydroxyphytanyl methyl ester was unsatisfactory due to adsorptive losses on the column.

Human serum albumin labeled with ${ }^{131} \mathrm{I}$ was obtained from E. R. Squibb \& Sons, New York, and used without further purification.

Patient material and initiation of tissue cultures. Three patients with HAP, all of whom had elevated plasma phytanate concentrations, served as donors of tissue for culture. Two, J. S. and K. S., are Irish siblings, first reported in detail by Ashenhurst, Millar, and Milliken (22), and subsequently studied at the Clinical Center (8). M. G. is a 23 year old French female whose case history has been reported by Bonduelle and coworkers (23). Control cultures were derived from four normal volunteers, one patient each with amyloidosis, Niemann-Pick disease, Hurler's syndrome, homocystinuria, and several with as yet undiagnosed storage diseases involving complex lipids.

Methods used in initiating and maintaining fibroblast tissue cultures have been previously described (24). Biopsies taken in the Clinical Center at NIH were immediately minced and placed in sterile culture medium. Biopsies taken abroad were placed in a vial containing a few milliliters of sterile medium, packed in ice, and shipped air express to Bethesda (48-72 $\mathrm{hr}$ en route). Monolayer cultures were established in $200-\mathrm{ml} \mathrm{milk}$ dilution bottles containing $10 \mathrm{ml}$ of medium gassed with $5 \% \mathrm{CO}_{2}$ in air. In each culture, cells having the spindle shape characteristic of fibroblasts overgrew the early outgrowth of flattened epithelial elements. When studies were performed (during the third through twentieth passage in culture) all the cells appeared fibroblastic.

Cultures were initiated and maintained in Eagle's minimal essential medium, modified to contain $0.16 \%$ sodium bicarbonate and supplemented with nonessential amino acids (25), neomycin $(50 \mu \mathrm{g} / \mathrm{ml})$, and phenol red $(0.01 \%)$. Fetal bovine serum (not heat inactivated) was incorporated in all media. Final serum concentration was $10 \%$ except in incubations with radioactive fatty acids, when serum concentration varied from 1 to $5 \%$, depending on the amount of substrate used. Medium $\mathrm{pH}$ was adjusted to between 7.3 and 7.4 and incubations were carried out at $36.5^{\circ} \mathrm{C}$ in $32-\mathrm{oz}$ prescription bottles containing $20 \mathrm{ml}$ of medium and between $1 \times 10^{7}$ and $2 \times 10^{7}$ cells in a stationary growth phase. Labeled fatty acids were either added directly to the serum-containing medium just before Millipore filtration or were first complexed with fetal bovine serum or human serum albumin, sterilized by filtration through prewashed Millipore filters, and then added to the culture. In all cases, the final preparation was clear, indicating completeness of complex formation with albumin.

Measurement of fatty acid oxidation. At the end of the incubation, ${ }^{14} \mathrm{CO}_{2}$ was released from the medium by acidifying to $\mathrm{pH} 2$ with $\mathrm{HCl}$. An aliquot of medium was withdrawn through the rubber serum cap for determination of aqueous tritium (released from palmitic acid- ${ }^{8} \mathrm{H}$ ). During withdrawal of medium, the bottle was oriented so that the surface covered with cells remained uppermost and thus was not exposed to the acidified medium. The gas phase in the buttle was drawn slowly through $10 \mathrm{ml}$ of $5.1 \mathrm{~N} \mathrm{NaOH}$ while being displaced by saline, which entered through a second needle. With approximately $80 \%$ of the atmosphere collected, the bottle's liquid content was returned to neutrality with $\mathrm{NaOH}$ and the remaining gas was collected. The cell sheet was then washed three times with $\mathrm{Ca}^{++}$- and $\mathrm{Mg}^{++}$-free Dulbecco's saline (26), dispersed and collected using a small volume of $0.05 \%$ trypsin, $0.005 \%$ ethylenediaminetetraacetate (EDTA), and $0.2 \%$ methyl cellulose. An aliquot of the cell suspension was removed for enumeration in a Coulter counter. The remainder was washed in Dulbecco's saline and sonically disrupted before determination of total protein (27) and lipid radioactivity.

The $\mathrm{NaOH}$ containing $\mathrm{Na}_{2}{ }^{14} \mathrm{CO}_{3}$ was slurried with $3.000 \mathrm{~g}$ of highly purified anthracene crystals (Fluorescence Grade, X 480, Eastman Kodak Company, Rochester, N. Y.) and $0.2 \mathrm{ml}$ of a solution of Triton, GR-5, diluted 1:10 v/v (Lot 5729, Rohm \& Haas Co., Philadelphia, Pa.) and counted in a liquid scintillation spectrometer (Packard Tri-Carb, model $314 \mathrm{EX}$ ) (28). The rate of oxidation of palmitic acid was also determined in each of the cultures studied. In our earliest experiments, one bottle of cells was incubated with palmitic acid- $1-{ }^{14} \mathrm{C}$, while a duplicate bottle was incubated with the branched-chain acid under study. In later studies, palmitate oxidation was determined simultaneously with that of the ${ }^{14} \mathrm{C}$-labeled branched-chain compounds by including palmitic acid- $9,10-^{3} \mathrm{H}$ in the same medium. Duplicate aliquots of medium withdrawn at the end of the incubation period were neutralized and lyophilized; the tritium content of the water distilled off was determined in a dioxane-containing scintillation mixture (29).

Analysis of cell lipid radioactivity. Lipids were extracted from aqueous suspensions of sonically disrupted cells and from medium using chloroform-methanol $2: 1(25 \mathrm{ml} / \mathrm{ml})$. After addition of one-fifth volume of $0.02 \mathrm{~N} \mathrm{H}_{2} \mathrm{SO}_{4}$, chloroform and aqueous phases were separated. In some cases, free fatty acids (FFA) were extracted from the total lipid sample before saponification (30); in others, the total lipid fraction (including FFA) was heated at about $80^{\circ} \mathrm{C}$ for $1-2 \mathrm{hr}$ in $2 \%$ $\mathrm{NaOH}$ in $95 \%$ ethanol (at least $2 \mathrm{ml} / \mathrm{mg}$ lipid). An equal volume of distilled water was added and the nonsaponifiable lipids were extracted by shaking three times with equal volumes of hexane. The residual alkaline aqueous phase was acidified and the saponifiable fraction similarly extracted, occasionally with an additional final diethyl ether extraction.

The FFA fraction and the esterified fatty acid fraction from each culture were converted to methyl esters by heating overnight at $60^{\circ} \mathrm{C}$ in $2 \% \mathrm{H}_{2} \mathrm{SO}_{4}$ in anhydrous methanol. Radioactivity in individual fatty acid methyl esters was assayed by gas-liquid radiochromatography (16). Resolution of branched-chain and straight-chain fatty acids was achieved using a mixed liquid phase (7\% EGS plus $1.5 \%$ SE-30 on 
Gaschrom Q) at $175^{\circ}-185^{\circ} \mathrm{C}$ with $\mathrm{N}_{2}$ carrier gas flow of 80 $\mathrm{ml} / \mathrm{min}$.

Labeled $\alpha$-hydroxyphytanic acid in cell extracts was first partially purified by TLC of the total fatty acid methyl esters after addition of carrier methyl $\alpha$-hydroxyphytanate (silica gel containing $0.1 \%$ Rhodamine $6 \mathrm{G}$; developing solvent : benzene-hexane, $2: 1 ; R_{\mathbb{f}}$ of $\alpha$-hydroxyphytanate, approximately 0.2$)$. The radioactivity specifically associated with $\alpha$-hydroxyphytanate was then determined by gas-liquid radiochromatography (17\% EGS on Chromosorb W).

\section{RESULTS}

Time course of fatty acid oxidation in tissue culture

The time course of ${ }^{14} \mathrm{CO}_{2}$ evolution from labeled fatty acids in tissue culture was examined in two ways. In one experiment gas in individual culture bottles was repeatedly sampled at 8 - or $12-\mathrm{hr}$ intervals over a $72 \mathrm{hr}$ period. While minor losses of ${ }^{14} \mathrm{CO}_{2}$ with this procedure could not be excluded, results of two experiments, shown in Fig. 2, indicate that production of ${ }^{14} \mathrm{CO}_{2}$ from labeled palmitate and pristanate is linear for at least the 1 st $48 \mathrm{hr}$ both in control and HAP cultures.

Using a second approach, bottles were removed at intervals from a group of replicates in which approximately equal numbers of cells of the same strain and at the same stage of growth had been incubated with identical

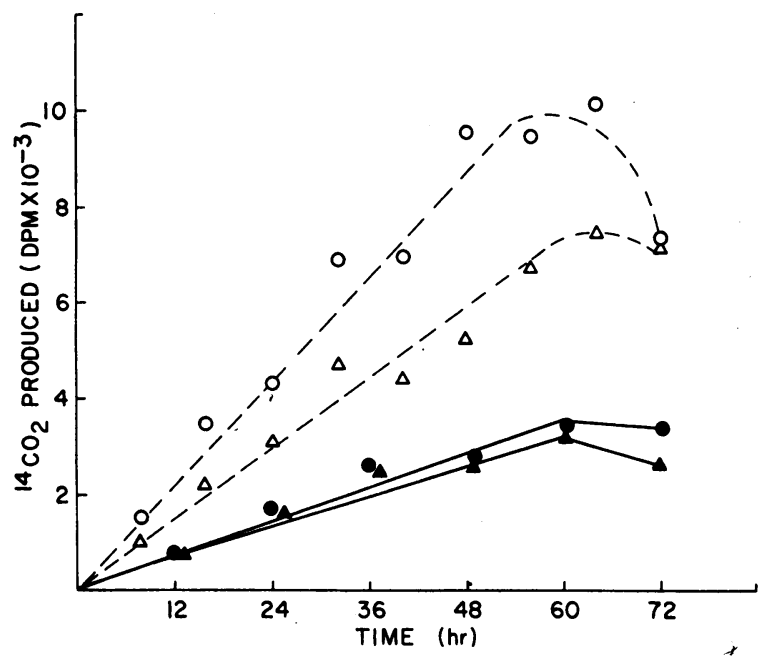

FIGURE 2 Time course of ${ }^{14} \mathrm{CO}_{2}$ production from pristanate$\mathrm{U}-{ }^{14} \mathrm{C}(O, \Delta)$ and palmitate-1-14 $\mathrm{C}(\boldsymbol{0}, \mathbf{\Delta})$ measured by repeated sampling from individual flasks. Two HAP strains $(O, \bullet)$ and two control strains $(\Delta, \boldsymbol{\Delta})$ were used. In one experiment $0.007 \mu$ moles of pristanate-U- ${ }^{14} \mathrm{C} \quad(\mathrm{SA}=33 \mu \mathrm{c} /$ $\mu \mathrm{m})$ was added to an $\operatorname{HAP}(O)$ and to a control $(\triangle)$ strain in medium with pristanate: albumin molar ratio of 0.02 . In the second experiment $2.7 \mu$ moles of palmitate- $1-{ }^{14} \mathrm{C}$ $(\mathrm{sA}=0.06 \mu \mathrm{c} / \mu \mathrm{m})$ was added to an HAP (๑) and to a control ( $\boldsymbol{\Delta})$ strain in medium with palmitate: albumin molar ratio of 6.0. See text for details of incubation and sampling procedure.

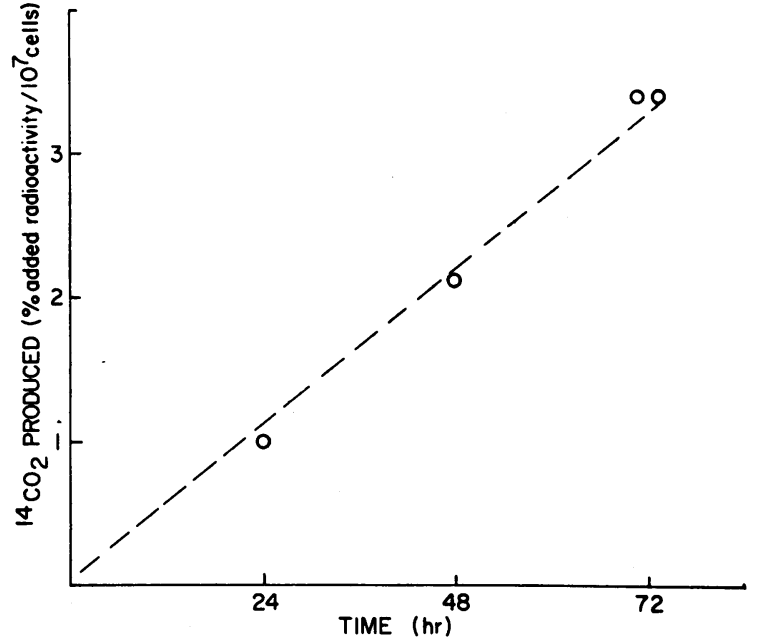

Figure 3 Time course of ${ }^{11} \mathrm{CO}_{2}$ production from homophytanate-U- ${ }^{14} \mathrm{C}$ by replicate control cultures. $0.6 \mu$ moles of homophytanate-U $-{ }^{14} \mathrm{C}(\mathrm{SA}=0.18 \mu \mathrm{c} / \mu \mathrm{m})$ was added to each of four cultures in media with homophytanate : albumin molar ratio of 2.0. See Methods for details of incubation procedure.

aliquots of labeled fatty acid. Results of one such study, in which the $(n+1)$ homologue of phytanic acid, homophytanic acid, was added to a control cell strain, are shown in Fig. 3. A constant rate of production of ${ }^{14} \mathrm{CO}_{2}$ was observed in this study also.

In further studies, $48 \mathrm{hr}$ was chosen as the standard incubation time. Several conditions must be observed in order to maintain constant rates of oxidation. The initial ratio of FFA to albumin in the medium must not be too low; evidently uptake falls off as the FFA : albumin molar ratio falls to very low values during the incubation, as reported by Spector and Steinberg for studies with ascites tumor cells (31). The cell culture must be in a stationary phase, since the cell count at the end of the 48 $\mathrm{hr}$ incubation period is used as the basis for expressing results. At albumin concentrations less than 1\%, nonlinear rates of oxidation were observed, possibly because the total amount of fatty acid that could be added (and still keep all of the FFA bound to albumin) was so low that a significant fraction of it was utilized in the course of the $48 \mathrm{hr}$ incubation period, causing the substrate concentration to fall over the course of the incubation.

\section{Fatty acid oxidation in control and HAP cultures}

Table I summarizes the comparative rates of oxidation in control and HAP cultures of labeled phytanate, pristanate, $\alpha$-hydroxyphytanate, and palmitate. In each case the medium used was exactly the same for the control and HAP cells. The defect in phytanate oxidation is apparent. The rate in HAP cultures was on the average less than $3 \%$ of the rate in control cultures. In no 
TABLE I

Oxidation of Branched-Chain and Straight-Chain Fatty Acids by Control and HAP Cell Cultures

\begin{tabular}{|c|c|c|c|c|}
\hline & Phytanate-U-14C & Pristanate-U-14C C & $\begin{array}{c}\alpha-\mathrm{OH}-\text { phytanate- } \\
\text { U-14 C }\end{array}$ & Palmitate-1-14C \\
\hline \multicolumn{4}{|c|}{$\begin{array}{l}\text { A. Oxidation of labeled fatty acids (percentage of added radioactivity converted } \\
\text { to }{ }^{14} \mathrm{CO}_{2} / 48 \mathrm{hr} \text { per } 10^{7} \text { cells) }\end{array}$} & . \\
\hline $\begin{array}{l}\text { HAP cultures } \\
\text { Control cultures }\end{array}$ & $\begin{array}{c}0.04 \pm 0.02(8)^{*} \\
3.4 \pm 0.79(14) \\
(P<0.001)\end{array}$ & $\begin{array}{l}6.7 \pm 0.2(13) \\
6.4 \pm 0.85(11)\end{array}$ & $\begin{array}{l}0.20 \pm 0.08(6) \\
0.19 \pm 0.12(4)\end{array}$ & $\begin{array}{l}10.9 \pm 0.96(27) \\
11.6 \pm 1.6(27)\end{array}$ \\
\hline \multicolumn{5}{|c|}{$\begin{array}{l}\text { B. Oxidation of }{ }^{14} \mathrm{C} \text {-labeled substrates relative to simultaneously measured }{ }^{3} \mathrm{H} \text {-palmitate oxidation, } \\
\left(\text { percentage added }{ }^{14} \mathrm{C} \text { in }{ }^{14} \mathrm{CO}_{2}\right) /\left(\text { percentage added }{ }^{3} \mathrm{H} \text { in }{ }^{3} \mathrm{H}_{2} \mathrm{O}\right) \times 100\end{array}$} \\
\hline $\begin{array}{l}\text { HAP cultures } \\
\text { Control cultures }\end{array}$ & $\begin{aligned} 0.39 & \pm 0.11(12)^{*} \\
15.0 & \pm 4.1 \quad(11) \\
(P & <0.002)\end{aligned}$ & $\begin{array}{l}39 \pm 6.1(9) \\
49 \pm 6.2(8)\end{array}$ & $\begin{array}{l}1.8 \pm 0.9(6) \\
1.2 \pm 0.4(3)\end{array}$ & - \\
\hline
\end{tabular}

* Results represent means \pm SEM ; No. of observations in parentheses.

case did the rate in HAP cultures exceed $5 \%$ of the control rate.

In contrast, pristanate, previously shown to be an early intermediate on the pathway of phytanate degradation, was oxidized at the same high rate in both control and HAP cultures. There was no significant difference between control cultures and HAP cultures in the rate of oxidation of $\alpha$-hydroxyphytanate. In control cultures, however, the rate of oxidation of $\alpha$-hydroxyphytanate was considerably slower than that of either phytanate or pristanate. This slow oxidation may reflect difficulty in penetration into mitochondrial sites of oxidation. Recent studies ${ }^{2}$ show that oxidation of $\alpha$-hydroxyphytanate by isolated rat liver mitochondria is slower than that of phytanate but is strongly stimulated by addition of carnitine. In Table I, the data for both less polar and more polar isomers have ben pooled. The separate results with each isomeric fraction are discussed below.

Finally, as shown in Table I, palmitate was oxidized at comparable high rates in control and HAP cultures. As shown in Table I B normalizing results to equal rates of palmitate oxidation does not affect the conclusions.

\section{Oxidation of $\alpha$-hydroxyphytanate isomers}

As discussed under Methods, the synthesis of $\alpha$-hydroxyphytanate- $\mathrm{U}_{-}{ }^{14} \mathrm{C}$ is expected to yield four isomeric products based on stereoisomerism at the 2-position (hydroxyl group $\mathrm{D}$ or $\mathrm{L}$ ) and at the 3-position (methyl group D or L) (see Fig. 1). One of the two bands resolved by TLC is assumed to include (2-D, 3-D) plus (2-L, 3-L), while the other includes (2-D, 3-L) plus (2-L, 3-D) $\alpha$-hydroxyphytanate. Which mixture is represented in the less polar and which in the more polar TLC band is not known. In Table II is shown a comparison of the rates of oxidation of these isomeric mixtures. In both control and HAP cultures the less polar mixture was oxidized more rapidly than the more polar mixture. The less polar mixture is also oxidized more rapidly by rat liver mitochondria. ${ }^{2}$ When the results are ${ }^{2}$ S. C. Tsai, J. Avigan, and D. Steinberg. Unpublished results.

TABLE II

Oxidation of Isomers of Alpha-Hydroxyphytanate-U_-14 C by HAP and Control Cells

\begin{tabular}{|c|c|c|c|c|c|}
\hline \multirow[b]{2}{*}{$\begin{array}{l}\text { Origin of } \\
\text { culture }\end{array}$} & \multicolumn{5}{|c|}{${ }^{14} \mathrm{CO}_{2}$ or ${ }^{3} \mathrm{H}_{2} \mathrm{O}$ (percentage of added radioactivity $/ 48 \mathrm{hr}$ per $10^{7}$ cells) } \\
\hline & $\begin{array}{c}\text { A } \\
{ }^{\text {MC-hydroxyphytanate, }} \\
\text { less polar isomers }\end{array}$ & 'H-palmitate & $\begin{array}{c}\text { C } \\
{ }^{14} \text { C-hydroxyphytanate, } \\
\text { more polar isomers }\end{array}$ & ${ }^{2} \mathrm{H}$-palmitate & $\begin{array}{c}\text { Relative rates of } \\
\text { oxidation of } \\
\text { hydroxyphytanate } \\
\text { isomers (corrected) }\end{array}$ \\
\hline HAP $_{1}$ & 0.059 & 7.8 & 0.038 & 11.8 & 2.4 \\
\hline $\mathrm{HAP}_{2}$ & 0.13 & 7.0 & 0.048 & 10.0 & 3.9 \\
\hline Control & 0.059 & 5.0 & 0.035 & 7.1 & 2.4 \\
\hline
\end{tabular}

* ${ }^{14} \mathrm{CO}_{2}$ produced from each isomer was normalized to equal palmitate-9, $10-{ }^{3} \mathrm{H}$ oxidation (A/B and C/D), and a corrected ratio was then calculated for expressing the relative rates of oxidation of the hydroxyphytanate isomers. This procedure may be interpreted as correcting for differences in cell number and metabolic activity of cells. 
expressed relative to the simultaneously measured rate of palmitate oxidation (last column in Table II), it is seen that the less polar isomers were oxidized two to three times more rapidly. Evidently there is some degree of stereospecificity but no absolute specificity in the enzymatic handling of $\alpha$-hydroxyphytanate, and this is similar in control and in HAP cells. The important point in the present context is that the HAP cultures oxidized both isomeric fractions at least as well as did the control cultures.

\section{Analysis of cell lipid radioactivity}

To establish first that analyses of cell lipid radioactivity were measuring only firmly bound or incorporated lipid and to evaluate the contribution from adsorbed albumin-bound fatty acid, ${ }^{121}$ I-labeled human serum albumin (HSA) was incubated with a culture for $48 \mathrm{hr}$ and the washed cells were examined for retained radioactivity. Table III shows that the cell pellet contained only about $0.01 \%$ of the initial medium radioactivity. Thus, a culture containing $2 \times 10^{7}$ cells would have irreversibly adsorbed or incorporated only about $1 \mathrm{~m} \mu$ mole of albumin in $48 \mathrm{hr}$ or, assuming a constant rate, $6 \times 10^{5}$ molecules/cell per $\mathrm{hr}$. This figures agrees closely with results of published studies on the rate of albumin uptake by human and animal tumor cells in culture $(32,33)$. Uptake of FFA attributable to uptake or adsorption of albumin is insignificant, then, relative to the observed over-all rates of fatty acid uptake and

TABLE III

Uptake of ${ }^{131}$ I-labeled Human Serum Albumin by Normal Fibroblasts*

\begin{tabular}{lcc}
\hline \multicolumn{1}{c}{ Sample } & $\begin{array}{c}\text { Total radioactivity } \\
\text { in sample }\end{array}$ & $\begin{array}{c}\text { Percentage of } \\
\text { medium radio- } \\
\text { activity present } \\
\text { in cell pellet }\end{array}$ \\
\hline $\begin{array}{c}\text { Cell pellet } \\
\text { Incubated medium, } \\
(1 \mathrm{ml})\end{array}$ & 533 & $\frac{\%}{\text { chm }}$ \\
$\begin{array}{c}\text { Unincubated medium, } \\
(1 \mathrm{ml})\end{array}$ & $4,880,000$ & 0.011 \\
\hline
\end{tabular}

* $8 \mu \mathrm{c}$ of ${ }^{131} \mathrm{I}$-HSA ( $\mathrm{SA}=185 \mu \mathrm{c} / \mathrm{mole}$ ) were added to $25 \mathrm{ml}$ of medium containing $0.02 \%$ albumin. Final albumin concentration in the $20-\mathrm{ml}$ portion incubated with the culture was $0.032 \%$, equivalent to $1.6 \%$ serum having an albumin concentration of $2 \%$. At the end of $48 \mathrm{hr}$, the cells were washed, dispersed, and collected in conventional fashion. Radioactivity was measured in the medium that had been incubated with the cells, in an aliquot of unincubated medium, and in the cell pellet. Each value represents the mean of three 1-min counts in a Nuclear-Chicago well-type gamma counter, model 183.
TABLE IV

Oxidation and Cell Uptake of Phytanic acid-U $-{ }^{14} C$ in Control and HAP Cultures*

\begin{tabular}{clccc}
\hline & \multicolumn{3}{c}{$\begin{array}{c}\text { Percentage of added radio- } \\
\text { activity per } 10^{7} \text { cells in : }\end{array}$} \\
\cline { 2 - 4 } $\begin{array}{c}\text { Origin of } \\
\text { culture }\end{array}$ & $\mathrm{CO}_{2}$ & $\begin{array}{c}\text { Total } \\
\text { lipid }\end{array}$ & $\begin{array}{c}\mathrm{CO}_{2}+ \\
\text { total } \\
\text { lipid }\end{array}$ & $\begin{array}{c}\text { Percentage } \\
\text { of total lipid } \\
\text { radioactivity } \\
\text { in FFA }\end{array}$ \\
\hline HAP & & & & \\
1 & 0.124 & 17.9 & 18.0 & 30 \\
2 & 0.075 & 22.1 & 22.2 & 20 \\
3 & 0.003 & 21.2 & 21.2 & 25 \\
4 & 0.06 & 14.3 & 14.4 & 19 \\
Control & & & & \\
1 & 5.2 & 7.7 & 12.9 & 24 \\
2 & 7.9 & 7.3 & 15.2 & 30 \\
\hline
\end{tabular}

* Analysis after 48 -hr incubations. Each line represents results obtained with a single culture.

oxidation, which were two to three orders of magnitude greater.

Uptake of labeled phytanate and oxidation to $\mathrm{CO}_{2}$ were determined in 48-hr incubations. Typical experimental results are shown in Table IV. As already noted, oxidation to $\mathrm{CO}_{2}$ by HAP cultures was drastically reduced. However, there was a much greater accumulation of phytanic acid radioactivity in the HAP cultures. The total taken up $\left({ }^{14} \mathrm{CO}_{2}\right.$ plus ${ }^{14} \mathrm{C}$-lipid) was thus virtually the same in control and HAP cultures. As shown in the last column of Table IV, 20-30\% of the cell lipid radioactivity was in the FFA fraction in both control and HAP cells. These findings suggest that the low yield of ${ }^{14} \mathrm{CO}_{2}$ from phytanate- $\mathrm{U}^{14} \mathrm{C}$ was not due to impaired uptake from the medium.

\section{TABLE V}

Comparison of Palmitate-1 $-{ }^{14} \mathrm{C}$ and Phytanate- $U-{ }^{14} \mathrm{C}$ Oxidation and Uptake by Control Cultures*

\begin{tabular}{ccccc}
\hline & \multicolumn{3}{c}{$\begin{array}{c}\text { Percentage of added radio- } \\
\text { activity per } 10^{7} \text { cells in: }\end{array}$} & $\begin{array}{c}\text { Percentage } \\
\text { of total lipid }\end{array}$ \\
\cline { 2 - 3 } FA added & $\mathrm{CO}_{2}$ & $\begin{array}{c}\text { Total } \\
\text { lipid }\end{array}$ & $\begin{array}{c}\mathrm{CO}_{2}+ \\
\text { total } \\
\text { lipid }\end{array}$ & $\begin{array}{c}\text { radioactivity } \\
\text { in FFA }\end{array}$ \\
\hline Phytanate- & & & & $\%$ \\
U-14 & 5.8 & 3.4 & 9.2 & 49 \\
& 5.4 & 3.2 & 8.6 & 43 \\
Palmitate- & & & & \\
1-14C & 6.8 & 30.0 & 36.8 & 63 \\
& 5.5 & 25.7 & 31.2 & 61 \\
\hline
\end{tabular}

* Analysis after 72-hr incubation. Each line represents results obtained with a single culture. 

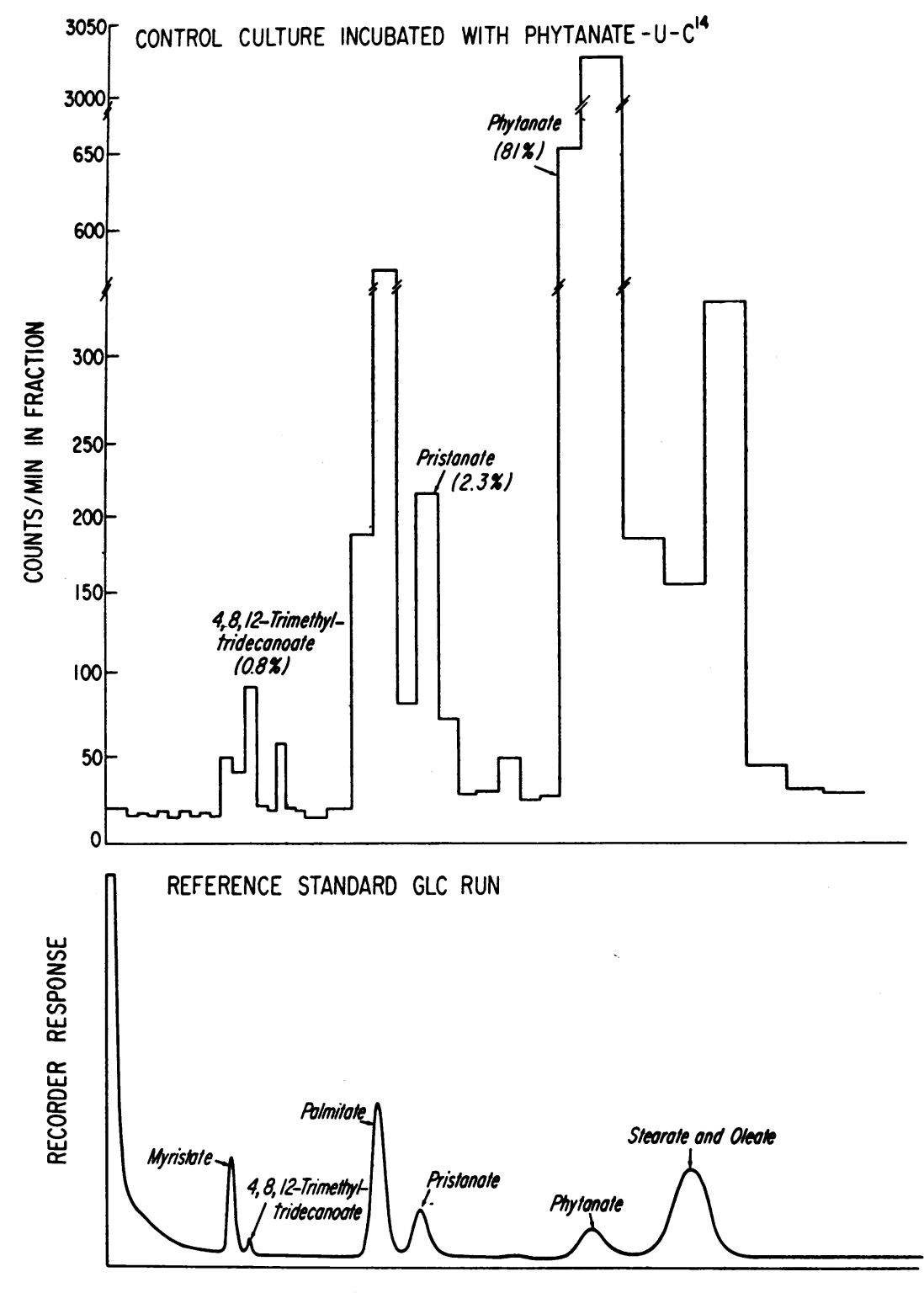

TIME

FIGURE 4 Gas-liquid radiochromatogram of methylated fatty acids derived from a control culture incubated $48 \mathrm{hr}$ with phytanic acid $-\mathrm{U}-{ }^{14} \mathrm{C}$. Radioactivity assayed in collected fractions is shown in upper part of figure. A standard fatty acid methyl ester mixture run under the same conditions is shown in lower part. The column was composed of a mixed liquid phase ( $7 \%$ EGS and 1-1/2\% SE-30 on Gas Chrom Q). Carrier gas flow was $80 \mathrm{ml} / \mathrm{min}$, column temperature $175^{\circ} \mathrm{C}$. The radioactive peaks corresponding to phytanate, pristanate and 4,8,12-trimethyltridecanoate are labeled and the percent each contributed to the total collected radioactivity given.

Oxidation and uptake of branched-chain acids (phytanate and pristanate) were compared with that of palmitate (Tables V and VI). The branched-chain acids were oxidized as rapidly as palmitate, but were incorporated much less rapidly into the lipid stores of the cells. The comparability in oxidation rates suggests that discrimination was not at the level of entry into the cell but rather at the level of esterification.

The distribution of radioactivity among the cell fatty acids at the end of 48 or $72 \mathrm{hr}$ of incubation was determined by gas-liquid radiochromatography of methyl esters. A representative analysis of a control culture is 
TABLE VI

Comparison of Palmitate- $1-{ }^{14} \mathrm{C}$ and Pristanate- $U-{ }^{14} \mathrm{C}$ Oxidation and Uptake by HAP and Control Cultures*

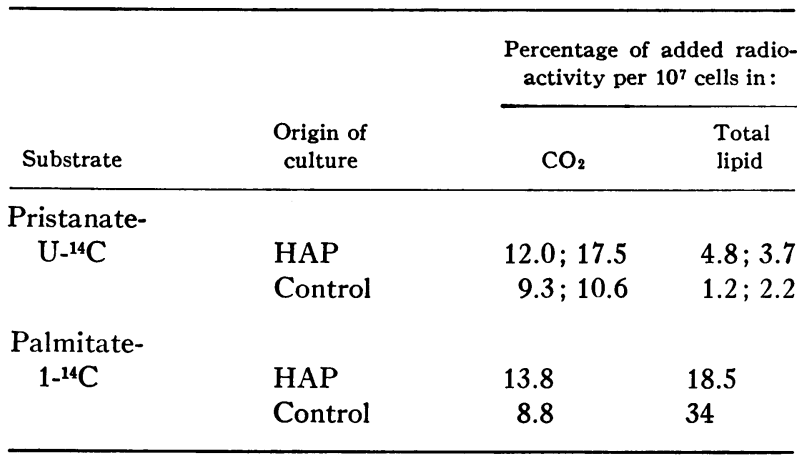

* Analyses after 48-hr incubation. Each value represents results obtained in a single culture, either of HAP or control cells.

shown in Fig. 4. In addition to the added substrate phytanate $-{ }^{14} \mathrm{C}$, there was significant radioactivity in pristanate and in 4,8,12-trimethyltridecanoate. The latter two fatty acids have been identified previously as degradation products on a major pathway for phytanic acid catabolism in animals (9-11). Quantitative results in four cell cultures of different origin are shown in Table VII. The present findings provide the first evidence that this same pathway is operative also in human cells. The appreciable incorporation of radioactivity into the normal 16-and 18-carbon fatty acids presumably occurred by breakdown of phytanate and reincorporation of labeled fragments.

The fatty acids extracted from an HAP culture similarly incubated with labeled phytanate showed, in striking contrast, only the parent phytanate peak (Fig. 5). Thus, there was no evidence either of breakdown into shorter branched-chain intermediates or of reincorporation of phytanate $-{ }^{14} \mathrm{C}$ into straight-chain fatty acids.

Control cultures yielded in addition a small GLC peak of radioactivity with a retention time about twice that of phytanate (Fig. 4). This radioactive component cochromatographed with authentic carrier $\alpha$-hydroxyphytanate on both a polar (EGS) and a nonpolar silicone liquid phase (OV-1). It accounted for $0.3-1.3 \%$ of total fatty acid radioactivity added to the control cultures (Table VII). None was detected in HAP cultures. As a further check on the identification of this radioactive component, the mixture of fatty acids (as methyl esters) derived from total lipids of two control cultures incubated with phytanate $-{ }^{14} \mathrm{C}$ were fractionated by TLC after addition of carrier methyl $\alpha$-hydroxyphytanate (benezene-hexane, $2: 1 ; \mathrm{R}_{\mathrm{r}}$ of hydroxyphytanate, $0.2)$. The material of the $\alpha$-hydroxyphytanate zone was eluted from the silicic acid and then fracionated by GLC. $70-80 \%$ of the total radioactivity in the TLC band cochromatographed on GLC with the carrier methyl $\alpha$-hydroxyphytanate.

Studies to rule out a metabolic block subsequent to formation of pristanic acid

The striking contrast between the relative inability of HAP cultures to oxidize phytanate and their almost normal ability to oxidize pristanate and $\alpha$-hydroxyphytanate indicated a metabolic block before the formation of the latter two metabolites. On the other hand, we still had to consider the possibility that the block lay distal to pristanate. The results could be compatible with this possibility on the following basis. The substrate concentrations of pristanate used when testing for its oxidation were probably considerably higher than those presented to the cell when pristanate was being generated by breakdown of substrate phytanate. Thus, for example, the cells might contain enzymes for pristanate oxidation that had a higher than normal $K_{m}$ value. When presented with a high concentration of pristanate in the medium, such an altered enzyme system might yield an over-all normal net rate of substrate utilization yet be unable to oxidize pristanate normally

TABLE VII

Distribution of Radioactivity among Cell Fatty Acids after 48- or 72-hr Incubations of Control Cultures with Phytanate- $U-{ }^{14} C^{*}$

\begin{tabular}{|c|c|c|c|c|c|c|}
\hline $\begin{array}{l}\text { Time of } \\
\text { incubation }\end{array}$ & Origin of Culture & Phytanate & $\begin{array}{c}\alpha \text {-Hydroxy- } \\
\text { phytanate }\end{array}$ & Pristanate & $\begin{array}{c}4,8,12- \\
\text { Trimethyl- } \\
\text { tridecanoate }\end{array}$ & $\begin{array}{l}\text { Straight-chain } \\
16-\text { and } 18- \\
\text { carbon fatty } \\
\text { acids }\end{array}$ \\
\hline \multicolumn{7}{|l|}{$(h r)$} \\
\hline 48 & A. B. (Hurler's syndrome) & 85.5 & 0.7 & 1.6 & 0.9 & 6.8 \\
\hline 48 & A. H. (retinitis pigmentosa) & 96.6 & 0.3 & 1.2 & 0.3 & 1.0 \\
\hline 72 & V. W. (undiagnosed lipidosis) & 60.3 & 0.8 & 1.9 & 0.6 & 23.8 \\
\hline 72 & R. D. (rheumatic heart disease) & 66.5 & 1.3 & 4.3 & 0.3 & 18.6 \\
\hline
\end{tabular}

* Values represent percentage of total radioactivity recovered from the GLC column cochromatographing with the components indicated. Small quantities of radioactivity were associated with unidentified peaks. 

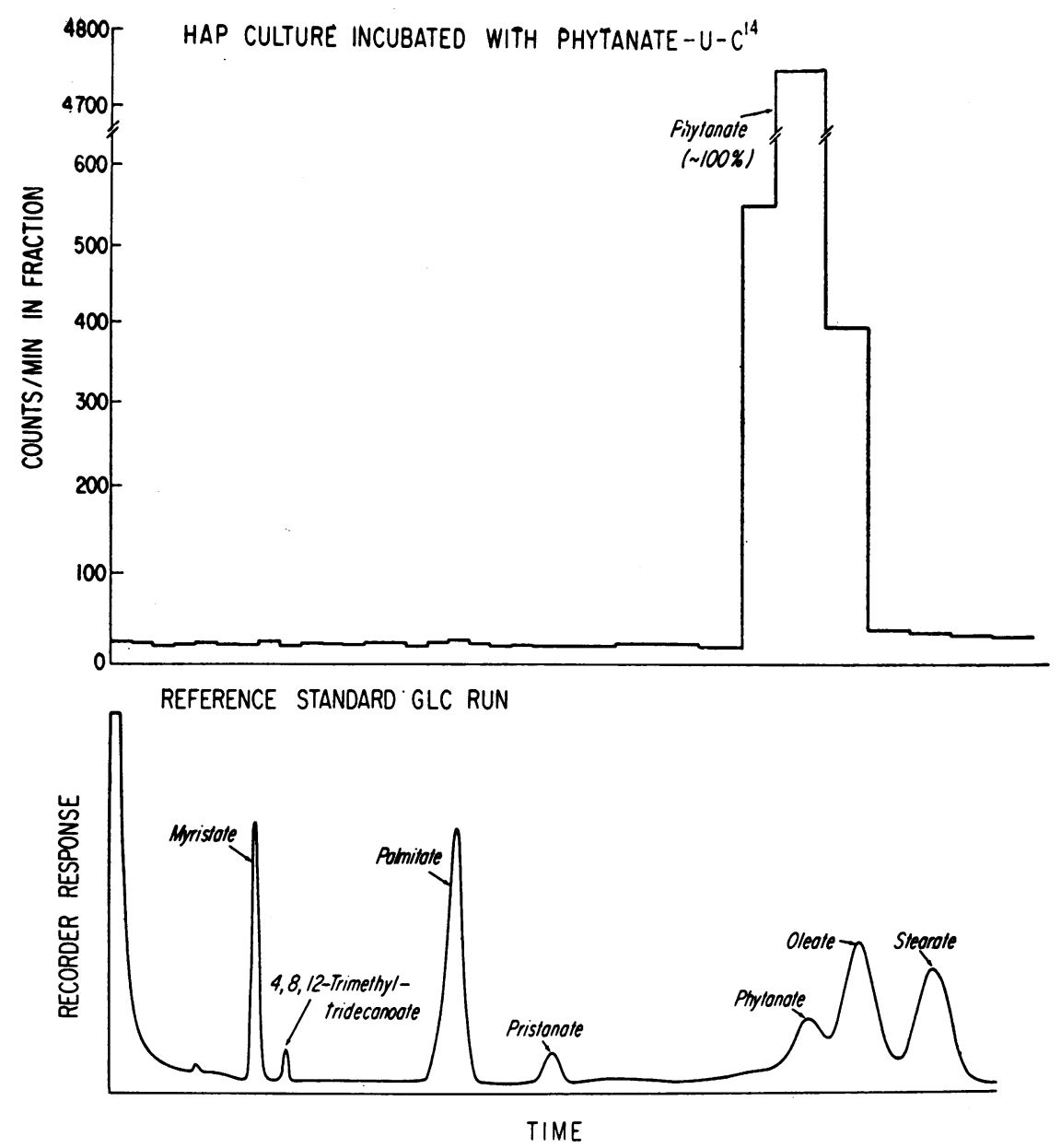

FIGURE 5 Gas-liquid radiochromatogram of methylated fatty acids derived from HAP culture incubated $48 \mathrm{hr}$ with phytanic acid-U- $-{ }^{14}$ C. See Fig. 4 for details.

when presented at low concentrations. Two approaches were taken to test this possibility.

(a) Comparisons at low substrate concentrations of pristanate. Control and HAP cultures were incubated with pristanate- $\mathrm{U}-{ }^{14} \mathrm{C}$ at two widely different concentrations: $0.0018 \mathrm{~m} \mu \mathrm{mole} / \mathrm{ml}$ and $1.56 \mathrm{~m} \mu \mathrm{mole} / \mathrm{ml}$. The study with the lower concentration required the synthesis of very high specific radioactivity pristanate$\mathrm{U}-{ }^{14} \mathrm{C}$. The low concentration of pristanate used approximated the concentration of pristanate calculated to be in the cells at the end of a $48 \mathrm{hr}$ incubation with phytanate in the medium. As shown in Table VIII, the fractional oxidation of pristanate at the low concentration was only slightly less than that at the high concentration. Oxidation of palmitate ${ }^{8} \mathrm{H}$ in the presence of the high concentration of pristanate was comparable to that seen at the lower level, i.e., the high FFA concentration was not noticeably toxic. The essential point here is that there was no important difference in the rate of prista-
TABLE VIII

Comparison of Oxidation of Pristanic Acid- $U-{ }^{14} C$ in $H A P$ and Control Cultures Incubated with High and with Low Levels of Substrate

\begin{tabular}{|c|c|c|c|c|}
\hline \multirow[b]{2}{*}{$\begin{array}{l}\text { 14-pristanate } \\
\text { concentration }\end{array}$} & \multirow[b]{2}{*}{$\begin{array}{l}\text { Origin of } \\
\text { culture }\end{array}$} & \multicolumn{2}{|c|}{$\begin{array}{c}{ }^{14} \mathrm{CO}_{2} \text { or }{ }^{8} \mathrm{H}_{2} \mathrm{O} \text { recovered } \\
\text { (per cent of added } \\
\text { radioactivity per } 48 \mathrm{hr} \\
\text { per } 10^{7} \text { cells) }\end{array}$} & \multirow{2}{*}{$\begin{array}{l}\text { Pristanat } \\
\text { oxidation } \\
\text { as per- } \\
\text { centage o } \\
\text { palmitate } \\
\text { oxidation }\end{array}$} \\
\hline & & $\begin{array}{l}\text { "C-pris- } \\
\text { tanate }\end{array}$ & $\begin{array}{l}\text { H-palmi- } \\
\text { tate }\end{array}$ & \\
\hline \multicolumn{5}{|l|}{ Low $(0.0018$} \\
\hline \multirow[t]{3}{*}{$\mathrm{m} \mu \mathrm{mole} / \mathrm{ml})^{*}$} & HAP 1 & 7.1 & 21.3 & 33 \\
\hline & HAP 2 & 4.3 & 10.0 & 43 \\
\hline & Control & 8.6 & 32.5 & 27 \\
\hline \multirow{4}{*}{$\begin{array}{l}\mathrm{High}(1.56 \\
\mathrm{m} \mu \mathrm{mole} / \mathrm{ml})^{*}\end{array}$} & & & & \\
\hline & HAP 1 & 7.8 & 19.8 & 39 \\
\hline & HAP 2 & 5.7 & 13.3 & 43 \\
\hline & Control & 9.5 & 29.7 & 32 \\
\hline
\end{tabular}

* Pristanate-U-14C of $\mathrm{SA}=33 \mu \mathrm{c} / \mu \mathrm{m}$ was used in lower level cultures; $\mathrm{SA}=1 \mu \mathrm{c} / \mu \mathrm{m}$ in higher level cultures. 
nate oxidation in HAP cells and in control cells. Indeed, if the data are normalized to equal rates of palmitate oxidation, the rate of pristanate oxidation in the HAP cells was somewhat greater than that in the control cells.

(b) Oxidation of homophytanic acid, the next higher homologue of phytanic acid. As discussed later, the metabolic error in HAP apparently involves the $\alpha$-oxidation system, whereas the $\beta$-oxidation system appears to be intact, as evidenced by the normal rates of oxidation of pristanic acid. If this interpretation is correct, HAP cells might be expected to oxidize the next higher homologue of phytanic acid, homophytanic acid, at a normal rate. In homophytanic acid (Fig. 6), the first branch-methyl group is in the gamma position and the beta position is available for oxidative attack as in classical beta oxidation. The product of such beta oxidation would be pristanic acid. Thus, the use of homophytanate ${ }^{14} \mathrm{C}$ as substrate provides a test of whether it is specifically the beta methyl group that makes phytanate difficult for HAP cells to metabolize. If oxidation of homophytanate were normal, it would also indicate that pristanate generated within the cells is in fact oxidized at a normal rate (see discusion above). As shown in Table IX, there was no difference between control and HAP cells in the rate of oxidation of homophytanate$\mathrm{U}-{ }^{14} \mathrm{C}$ nor in its total uptake into cell lipids.

\section{Release of phytanate from ester forms}

Another explanation considered for the poor rate of phytanate oxidation in HAP cells was that there might

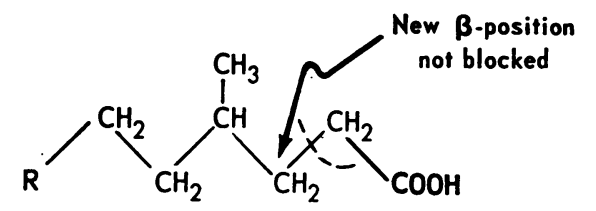

HOMOPHYTANIC ACID

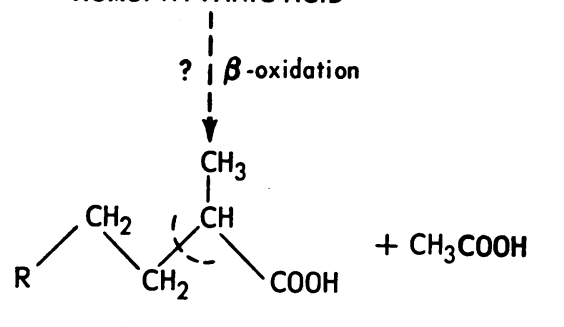

PRISTANIC ACID

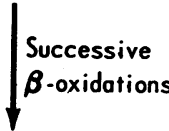

OXIDATION TO $\mathrm{CO}_{2}$

AT NORMAL RATE?

FIGURE 6 Oxidation of homophytanic acid, the next higher homologue of phytanic acid.
TABLE IX

Oxidation and Uptake of Homophytanate- $U-{ }^{14} \mathrm{C}$ and Palmitate9, $10-{ }^{3} \mathrm{H}$ by $\mathrm{HAP}$ and Control Cultures

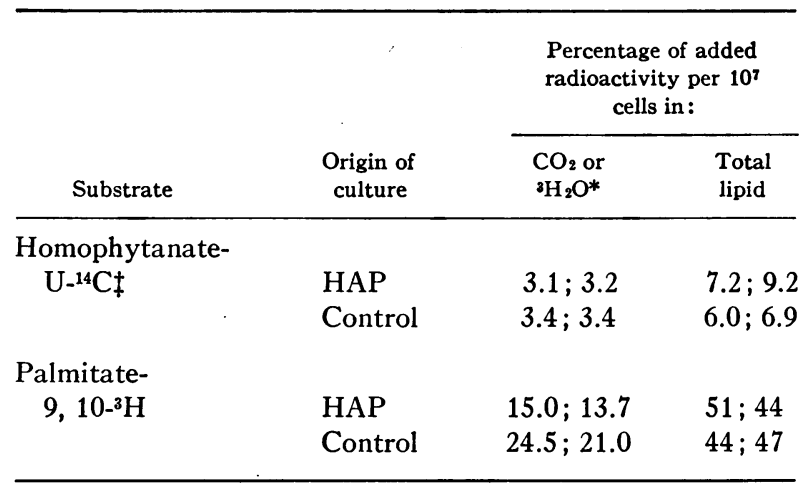

* Analysis after 48-hr incubation. Each value represents results obtained with a single culture.

$\ddagger$ Prepared from phytanate-U-14 $\mathrm{C}$; thus the carboxyl carbon was not labeled, but the remaining 20 carbons were uniformly labeled.

be a slow rate of release of phytanate from lipid esters. In other words, phytanate might be taken up and esterified normally but could not then be released and made available for oxidation, i.e., it might be "trapped" in ester forms. The following experiment was carried out in an attempt to detect differences in release of phytanate from previously labeled cells. Control and HAP strains were incubated for $48 \mathrm{hr}$ with ${ }^{14} \mathrm{C}$-labeled phytanate and palmitate $-{ }^{8} \mathrm{H}$ in the usual way. The cells were then washed free of labeled medium and fresh medium was added. The cells were next incubated for an additional $24 \mathrm{hr}$ in the unlabeled medium. ${ }^{14} \mathrm{CO}_{2}$ was collected, ${ }^{8} \mathrm{H}_{2} \mathrm{O}$ determined, and lipids were extracted from the medium by the method of Dole (34) and assayed for radioactivity. Cells were collected and cell lipid radioactivity measured. Intracellular radioactivity at the beginning of the second incubation was taken as the sum of cell lipid radioactivity and lipid radioactivity released to the medium. As shown in Table $\mathrm{X}$, control and HAP cells released nearly identical percentages of labeled endogenous material in $24 \mathrm{hr}$.

Other aliquots of medium were extracted similarly and separated into lipid classes by TLC (hexanediethyl ether-HAC, 90:10:2). Approximately $40 \%$ of the released radioactivity was in the free fatty acid zone. Gas-liquid radiochromatography showed that essentially all of this radioactivity was in phytanic acid in both HAP and control cultures. The TLC bands representing cholesterol and complex lipid esters each contained radioactivity, suggesting that membrane debris suspended in the medium contributed to the total lipid or that there was exchange with the lipoprotein lipids of the medium. 
TABLE $\mathrm{X}$

Release of Radioactivity from HAP and Control Cells Previously Labeled with Phytanate- $U-{ }^{14} C^{*}$

\begin{tabular}{ccc}
\hline & \multicolumn{2}{c}{$\begin{array}{c}\text { Percentage of cell lipid radioactivity } \\
\text { released to medium in 24 hrt }\end{array}$} \\
\cline { 2 - 3 } $\begin{array}{c}\text { Origin of } \\
\text { culture }\end{array}$ & ${ }^{4} \mathrm{C}$ & ${ }^{3 \mathrm{H}}$ \\
\hline HAP 1 & 48 & 10 \\
HAP 2 & 34 & 16.8 \\
Control & 43 & 6 \\
\hline
\end{tabular}

* Cells were labeled by incubation for $48 \mathrm{hr}$ with phytanate$\mathrm{U}-{ }^{14} \mathrm{C}$, washed, and then incubated for $24 \mathrm{hr}$ in fresh, unlabeled medium. The latter contained unlabeled pristanic acid (added in an attempt to trap released fatty acids). See text for details of procedure.

$\ddagger{ }^{14} \mathrm{C}$ and ${ }^{3} \mathrm{H}$ as percentage of calculated total cell lipid radioactivity present at beginning of second incubation. The latter was taken to be the sum of lipid radioactivity released and that extracted from cells at the end of the second incubation.

\section{Toxicity of branched-chain fatty acids}

Because fatty acid anions are known to be damaging to cell membranes under some circumstances, the possible contribution of such effects had to be considered. Two specific questions were tested experimentally. First, is phytanic acid more toxic to cultured fibroblasts than straight-chain fatty acids? Second, are fatty acids, in particular phytanic acid, more toxic to HAP cells than to normal cells in culture? One strain of control cells and two HAP strains were grown in medium containing free fatty acids over a wide range of concentrations. These concentrations were chosen to correspond to FFA : albumin molar ratios ranging from 0.025 to 6.4 . The effects of phytanic acid, pristanic acid, and palmitic acid were compared. Duplicate cultures exposed to each concentration of FFA were examined unstained under the light microscope after 24 and $48 \mathrm{hr}$ for the presence of cytoplasmic granulation and vacuolation, loss of cellular attachment to the glass surface, and disorganization of the cell sheet. Below FFA : albumin molar ratios of 3.2 there was no evidence of a toxic effect by these criteria. The abnormalities noted above were present in mild form at a molar ratio of 3.2 and were severe at a molar ratio of 6.4. However, there was no evident difference in toxicity among the three fatty acids tested, nor were there any evident differences in toxicity in control and HAP cells.

\section{DISCUSSION}

These tissue culture experimental results support and complement the conclusion drawn from clinical studies reported previously from this laboratory $(13,35)$, namely, that there is a primary block in phytanate degra- dation in HAP. In those reports and in a companion paper (36), it was shown that HAP patients converted orally administered phytol- ${ }^{14} \mathrm{C}$ or intravenously administered phytanic acid- ${ }^{14} \mathrm{C}$ to ${ }^{14} \mathrm{CO}$ at much slower rates than did normal controls. Phytanic acid radioactivity also persisted at much higher levels and for longer periods in the patients' plasma than in that of the controls. Although a metabolic block in the oxidation of phytanic acid seemed a likely explanation for these findings, this interpretation was complicated by the presence in the patients of large pools of unlabeled phytanate. While several lines of indirect evidence suggested that the fractional turnover of phytanic acid would not be grossly depressed by even large increases in pool size $(8,15)$, some dilutional effects could not be ruled out. In the present studies in cultured cells the problem of isotope dilution does not arise. GLC analyses of the HAP cell lipids after three to five pasages showed negligibly low phytanate levels. Both control and HAP cells showed traces of phytanate (probably attributable to the presence of phytanate in the fetal bovine serum used in the medium, less than $0.2 \%$ of total fatty acids). However, there was no difference between HAP and control cells in this regard. Accordingly, the greatly depressed rate of phytanic acid oxidation in HAP cultures, in none of which appreciable phytanate pools could be demonstrated, leaves little doubt that there is a primary defect. Preliminary results in fibroblast cultures from 11 additional documented cases of HAP have shown rates of phytanate oxidation less than $5 \%$ of the rates in control cultures. ${ }^{3}$

The present results lead us to conclude further that the defect lies in the conversion of phytanate to $\alpha$-hydroxyphytanate. This conclusion draws in part on our previously reported results in animals showing that a major oxidative pathway involves initial alpha-oxidation, to yield the $(n-1)$ fatty acid (pristanic acid), followed by successive beta oxidations to yield lower degradation products as shown in Fig. $7(9,10)$. That this is in fact a major pathway was shown by the very high yields of pristanic acid- ${ }^{14} \mathrm{C}$ after injection of phytanic acid- ${ }^{14} \mathrm{C}$. Moreover, after feeding of large doses of phytanic acid, GLC-mass spectrometry failed to reveal accumlation of any intermediates other than those shown in Fig. 7 even though spectra were obtained on all peaks. Nor, after injection of phytanate- ${ }^{14} \mathrm{C}$, was radioactivity found in any branched-chain acids other than those shown in Fig. 7. Hansen, Shorland, and Prior have confirmed the accumulation of pristanate and 4,8,12-trimethyltridecanoate in phytanic acid-fed rats $(37,38)$. More recently we showed that $\alpha$-hydroxyphytanate ${ }^{14} \mathrm{C}$ is formed from phytanate- ${ }^{14} \mathrm{C}$ in rat liver

\footnotetext{
${ }^{3}$ Herndon, J. H., Jr., B. W. Uhlendorf, and D. Steinberg. Unpublished results.
} 

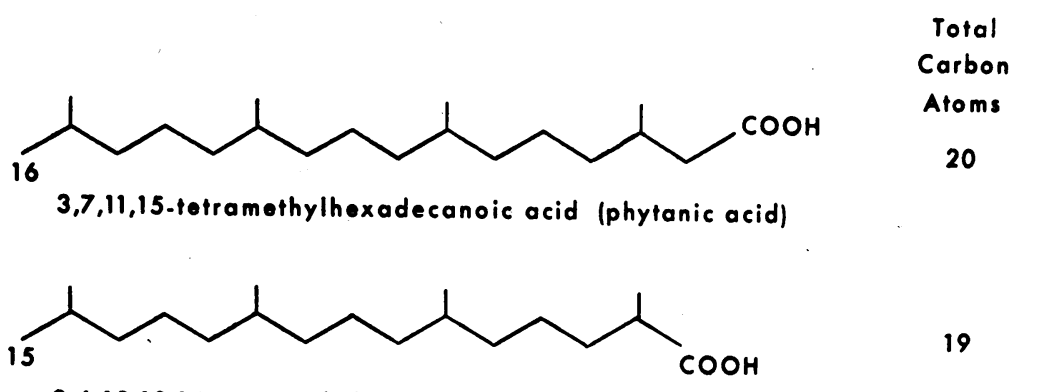

2,6,10,10,14-tetramethylpentadecanoic acid (pristanic acid)

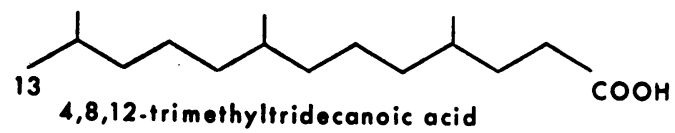

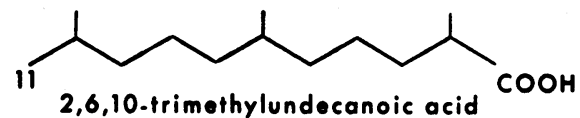<smiles>CC(C)CCCCCCCCCCCCCC(=O)O</smiles>

FIGURE 7 Identified intermediates of phytanic acid degradation. Breakdown products in a major oxidative pathway for phytanic acid, involving an initial $\alpha$-hydroxylation followed by oxidative removal of the first carbon; this loss results in formation of pristanic acid. Alternate removal of 3- and 2 -carbon fragments by $\beta$-oxidation could then produce the lower intermediates.

mitochondria and accumulates in livers of phytanic acidfed mice (11).

Having established the major pathway for degradation, we tested the capacity of HAP fibroblasts to oxidize the presumed metabolic products of phytanate. The rate of oxidation of $\alpha$-hydroxyphytanate- ${ }^{14} \mathrm{C}$ and of pristanate- ${ }^{14} \mathrm{C}$ were comparable in HAP and normal cells. If, and only if, these compounds are intermediates in the oxidation of phytanate, as they appear to be in the mouse and rat, do the results localize the metabolic error at this initial alpha hydroxylation step. Thus the analyses of labeled products of phytanate oxidation in the cell lipids are of central importance.

$\alpha$-hydroxyphytanate $-{ }^{14} \mathrm{C}$, pristanate- ${ }^{1 \mathrm{c}} \mathrm{C}$ and $4,8,12$-trimethyltridecanoate- ${ }^{14} \mathrm{C}$ were all identified in normal fibroblasts after incubation with phytanate- ${ }^{11} \mathrm{C}$. No other labeled compounds could be detected. These findings provide the first direct evidence that the alpha-oxidative pathway for phytanic acid oxidation described in animals occurs also in human cells. In contrast, the cell lipids in HAP cultures contained none of these compounds, only the added substrate phytanate- ${ }^{14} \mathrm{C}$ being demonstrable. All of these findings taken together ap- pear to justfy the conclusion that the HAP cells lack some component of an alpha-hydroxylating system (Fig. 8).

The results with homophytanate- ${ }^{14} \mathrm{C}$ provided important additional support for the localization of the enzymatic block. This $(n+1)$ homologue, as nearly similar as possible to phytanate with regard to physical and chemical properties was, like pristanate, oxidized and esterified by HAP cells at rates indistinguishable from those seen in control cells. In homophytanate the methyl substituent no longer blocks the beta carbon, but rather the gamma carbon. Consequently, homophytanate is susceptible to normal beta oxidation. The expected product, pristanic acid, has the methyl substituent on the alpha carbon and is also susceptible to normal beta oxidation. Thus, the next higher and the next lower homologues of phytanate are oxidized normally by HAP cells while phytanate itself is oxidized at only about $3 \%$ of the normal rate. Evidently it is specifically the betasubstitution that makes phytanate unavailable as a substrate in HAP cells.

Eldjarn and coworkers have approached the problem of identifying the enzyme error in HAP indirectly, by 


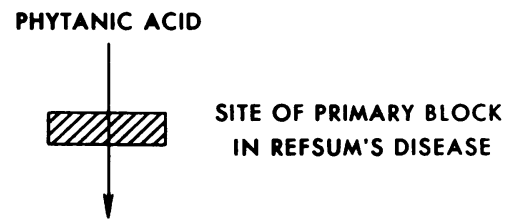

$\alpha$-HYDROXY PHYTANIC ACID

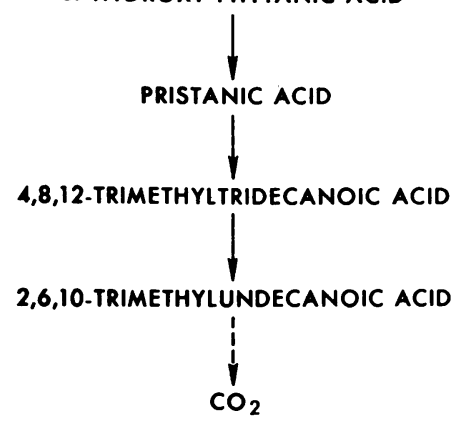

FIGURE 8 Proposed localization of the enzymatic block in degradation of phytanic acid in HAP patients.

using a variety of "model" compounds. The chain length and branching pattern of the "model" compounds used has not matched closely those of phytanate. Until more studies have been done on the substrate specificity of the enzymes involved in oxidation of branched-chain acids, the interpretation of results of these studies remains uncertain. Originally, Eldjarn concluded that patients with HAP accumulated phytanate because of a defect in omega oxidation, because after a loading dose of tricaprin they excreted a lower than normal amount of sebacic acid (the dicarboxylic acid resulting from omega oxidation of capric acid) (39). Further studies, however, showed that omega oxidation of a number of other compounds, including 2,2-dimethylstearic acid, was normal (40). Recently, Try and Eldjarn repeated the tricaprin loading test in two of the HAP patients after their plasma phytanate levels had been markedly reduced by dietary therapy (41). Now the tricaprin loading tests were within normal limits. It was concluded that the previous results reflected inhibition of omega oxidation by the accumulated stores of phytanate. On the other hand, the same laboratory showed that the main degradation products from orally administered 3,6dimethyloctanoic acid-8 $-{ }^{14} \mathrm{C}$ were omega oxidation products and that these were formed in comparable amounts by HAP patients and by controls (42). Neither in our earlier studies in vivo or in vitro $(9-11,15)$, nor in the present human cell culture studies have we been able to find evidence for formation of dicarboxylic acids derived from phytanate. Moreover, if it is assumed that the enzyme defect demonstrated here affects only alpha oxidation, one would have to conclude that the rate of omega oxidation of the compound occurs at less than $5 \%$ of the rate of alpha oxidation. It is of interest that Antony and Landau have recently presented evidence from ingenious isotope experiments indicating that omega oxidation of straight-chain acids is quantitatively unimportant in rat liver-less than $4 \%$ the rate of beta oxidation (43).

Because of the more or less close analogy in structure between phytanate and farnesoic acid, the latter being one isoprenoid unit shorter and being triply unsaturated, the possibility arose that $\mathrm{CO}_{2}$ fixation might be involved as it is in the mechanism described by Seubert and Remberger (44). An apparent $\mathrm{CO}_{2}$ requirement for oxidation of a "model" compound (3,6-dimethylactanoate) was noted by Eldjarn, Try, and Stokke (45), but this was subsequently attributed to changes in oxygen tension (42). Neither in the present studies nor in previous animal studies has there been evidence of the intermediate expected from an analogous pathway for phytanate degradation $(9-11,37,38)$. After administration of 3,6-dimethyloctanoate- $-8{ }^{14} \mathrm{C}$ to man, most of the urinary metabolites were omega oxidation products, as discussed above, but about $1.5 \%$ of the total was found in the $(n-1)$ acid $(42,46)$. HAP patients, on the other hand, excreted none of the alpha oxidation product and produced little or no ${ }^{14} \mathrm{CO}_{2}$. These results and recent studies by Stokke (47) provide confirmatory evidence for the presence of an alpha-oxidative pathway. They are also compatible with our conclusion regarding the nature of the metabolic error in HAP if this "model" compound is indeed oxidized by the same enzyme systems that oxidize phytanate. Because so large a fraction of 3,6-dimethyloctanoate is handled by omega oxidation, whereas this appears to be a minor pathway for phytanate oxidation, the validity of it as a model compound should be directly checked.

Try (48) has compared oxidation of 3,6-dimethyloctanoate-8 $-{ }^{14} \mathrm{C}$ and of randomly labeled 3,14,14-trimethylpentanoic acid in controls and in two HAP patients whose phytanate stores had been reduced by dietary means (49). The results indicated that the patients oxidized these compounds at one-third to one-half the normal rates. Labeled metabolites were excreted in amounts too low to be fully characterized. In view of the apparently very large capacity of the normal organism to metabolize phytanate (15), it is not certain that this degree of impairment would lead to phytanate accumulation. One cannot exclude the possibility that phytanate may be oxidized relatively more rapidly in vivo than in fibroblast cultures due to contributions of other organ and cell types. However, as reported in the accompanying paper (36), in vivo oxidation of phytanate itself in the three HAP patients studied here was impaired to an extent comparable to that seen in fibroblast cultures.

The present results demonstrate marked loss of phy- 
tanic acid- $\alpha$-hydroxylase activity, but do not differentiate among several possible explanations for it (suppression of enzyme protein synthesis, synthesis of an altered enzyme protein, impairment of a cofactor regenerating system, or other secondary basis for low activity). Assay of activity in cell-free systems with control of cofactor concentrations and, ultimately, isolation and characterization of the enzyme protein would be desirable. Recent studies in the rat have shown that the enzyme is predominantly intramitochondrial and suggest a role for $\mathrm{NADPH}$ and ferric ion (50). However, attempts to solubilize activity have thus far been unsuccessful.

The possibility has been raised that failure to hydrolyze phytanic acid contained in lipid esters may be involved in the pathogenesis of HAP (35). Although Laurell has shown that synthetic glyceryl triphytanate is resistant to hydrolysis by lipoprotein lipase obtained from healthy subjects after heparin injection (51), the enzymatic capacity of HAP patients, particularly with regard to release from tissue stores, has not been directly investigated. The present experiments with cultured human cells attempted to provide a direct test of the hypothesis. The finding that HAP and control strains released equivalent amounts of labeled phytanate after being washed and reincubated in unlabeled medium makes it seem unlikely that a defect in ester hydrolysis plays a major role in HAP.

The relationship between phytanate accumulation and the symptoms of HAP remains uncertain. Malfunction of lipid membranes into which phytanate is unavoidably incorporated represents the most straightforward hypothesis linking the two $(7,8,52)$. However, repeated attempts to induce neurological abnormalities in experimental animals by feeding phytol or phytanic acid, often at toxic levels and beginning during gestation $\left(53,54,{ }^{4}\right)$ have been unsuccessful. In the present study, short-term exposure of fibroblasts to moderate levels of unlabeled phytanic acid produced identical morphological changes in HAP and normal strains. These changes began at the same threshold level as did similar effects with palmitate. Subsequent studies extending over longer periods ${ }^{8}$ have provided suggestive evidence for a selective growth inhibitory effect of phytanic acid on HAP cultures. Consistent with this observation are reports of marked growth retardation in two cases of HAP presenting an unusually early onset soon after birth $(55,56)$. The possibility remains that displacement of normal structural fatty acids by excess phytanate may be responsible for the manifestations of HAP.

Another hypothesis would suppose that the alpha hydroxylating enzyme absent in HAP, in addition to

\footnotetext{
- Steinberg, D., and J. Avigan. Unpublished data.

' Herndon, J. H., Jr., D. Steinberg, and B. W. Uhlendorf. Manuscript in preparation.
}

disposing of phytanate, normally plays a second and more crucial metabolic role in nervous tissue. Considerable evidence exists for the occurrence of alpha oxidation and the participation of long-chain alpha hydroxy fatty acids in brain and nerve metabolism (57-59). However, attempts to demonstrate oxidation of phytanate in nervous tissue or alpha hydroxylation of lignocerate in cultured fibroblasts ${ }^{6}$ have so far been negative. Further, the phytanate oxidizing system has now been shown to have properties quite different from those of the brain alpha oxidizing system (60). Finally, two independent studies on postmortem tissue have failed to demonstrate abnormal patterns or concentrations of long-chain, straight-chain alpha hydroxy acids in HAP nervous tissue $(61,62)$.

A third possibility is that phytanic acid interferes with the function of fat-soluble vitamins such as $\mathrm{A}, \mathrm{E}$, or $\mathrm{K}$, or with other essential cofactors with closely related side chains. However, large doses of these materials or of unsaturated fatty acids failed to protect experimental animals against toxic effects of oral phytol $\left(53,{ }^{7}\right)$.

Finally, it remains possible that deletion of phytanate hydroxylation is separate from the defect responsible for the clinical manifestations of HAP but closely linked to it on the same chromosome. The proposal that on this or some other basis phytanate storage is not directly the cause of the clinical changes may also explain the discovery of patients who are clinically indistinguishable from those with HAP but who have normal phytanate levels, oxidize phytanate normally in vivo, and whose cultured fibroblasts oxidize phytanic acid at normal rates $\left(63,{ }^{8}\right)$. If further clinical observations confirm the previously noted improvement on phytanic acid-low diets (49), however, a simple cause and effect relationship can be accepted.

\section{ACKNOWLEDGMENT}

We are indebted to Dr. Philippe Laudat for making it possible to obtain a skin biopsy for culture from the patient M. G. in Paris.

\section{REFERENCES}

1. Refsum, S. 1946. Heredopathia atactica polyneuritiformis. Acta Psychiat. Scand. Suppl. 38: 9.

2. Kahlke, W. 1967. Heredopathia atactica polyneuritiformis (Refsum's disease). In Lipids and Lipidoses. G. Schettler, editor. Springer-Verlag New York Inc., New York.

3. Richterich, R., S. Rosin, and E. Rossi. 1965. Refsum's disease (Heredopathia atactica polyneuritiformis): an

- Blass, J. P., and J. H. Herndon, Jr. Unpublished data.

${ }^{7}$ Baxter, J. H. Unpublished data.

${ }^{8}$ Kayden, H. J., D. Steinberg, C. E. Mize, and J. H. Herndon, Jr. Unpublished results. 
inborn error of lipid metabolism with storage of 3,7,11,15tetramethyl hexadecanoic acid: formal genetics. Humangenetik. 1: 333 .

4. Klenk, E., and W. Kahlke. 1963. Über das Vorkommen der 3.7.11.15-Tetramethylhexadecansäure (Phytansäure) in den Cholesterinestern und anderen Lipoidfraktionen der Organe bei einem Krankheitsfall unbekannter Genese (Verdacht auf Heredopathia atactica polyneuritiformis -Refsum's Syndrome). Hoppe-Seyler's Z. Physiol. Chem. 333: 133.

5. Steinberg, D., J. Avigan, C. E. Mize, L. Eldjarn, K. Try, and S. Refsum. 1965. Conversion of U-C $C^{14}$-phytol to phytanic acid and its oxidation in heredopathia atactica polyneuritiformis. Biochem. Biophys. Res. Commun. 19: 783.

6. Steinberg, D., C. E. Mize, J. Avigan, H. M. Fales, L. Eldjarn, K. Try, O. Stokke, and S. Refsum. 1966. On the metabolic error in Refsum's disease. J. Clin. Invest. 45: 1076. (Abstr.)

7. Steinberg, D., C. E. Mize, J. Avigan, H. M. Fales, L. Eldjarn, K. Try, O. Stokke, and S. Refsum. 1966. On the metabolic error in Refsum's disease. Trans. Amer. Neurol. Ass. 91 : 168.

8. Steinberg, D., F. Q. Vroom, W. K. Engel, J. Cammermeyer, C. E. Mize, and J. Avigan. 1967. Refsum's disease-a recently characterized lipidosis involving the nervous system. Ann. Intern. Med. 66: 365.

9. Avigan, J., D. Steinberg, A. Gutman, C. E. Mize, and G. W. A. Milne. 1966. Alpha-decarboxylation, an important pathway for degradation of phytanic acid in animals. Biochem. Biophys. Res. Commun. 24: 838.

10. Mize, C. E., D. Steinberg, J. Avigan, H. M. Fales. 1966. A pathway for oxidative degradation of phytanic acid in mammals. Biochem. Biophys. Res. Commun. 25: 359.

11. Tsai, S-C., J. H. Herndon, Jr., B. W. Uhlendorf, H. M. Fales, and C. E. Mize. 1967. The formation of alphahydroxy phytanic acid from phytanic acid in mammalian tissues. Biochem. Biophys. Res. Commun. 28: 571.

12. Steinberg, D., J. H. Herndon, Jr., B. W. Uhlendorf, J. Avigan, C. E. Mize, and H. M. Fales. 1967. The enzymatic defect in Refsum's disease. J. Clin. Invest. 46: 1120.

13. Steinberg, D., J. H. Herndon, Jr., B. W. Uhlendorf, C. E. Mize, J. Avigan, and G. W. A. Milne. 1967. The nature of the enzyme defect in Refsum's disease. Science. 156: 1740 .

14. Mize, C. E., J. H. Herndon, Jr., S-C. Tsai, B. W. Uhlendorf, H. M. Fales, and D. Steinberg. 1968. Phytanic acid storage in Refsum's disease due to defective alpha-hydroxylation. Clin. Res. 16: 346. (Abstr.)

15. Mize, C. E., J. Avigan, J. H. Baxter, H. M. Fales, and D. Steinberg. 1966. Metabolism of phytol-U- ${ }^{14} \mathrm{C}$ and phytanic acid-U- ${ }^{14} \mathrm{C}$ in the rat. J. Lipid Res. 7: 692.

16. Karmen, A., L. Giuffrida, and R. L. Bowman. 1962. Radioassay by gas-liquid chromatography of lipids labeled with carbon-14. J. Lipid Res. 3: 44.

17. Ryhage, R., and E. Stenhagen. 1960. Mass spectrometric studies. IV. Methyl esters of normal chain oxo-, hydroxy-, methoxy- and epoxy acids. Ark. Kemi. 15: 545.

18. Burrell, J. W. K., L. M. Jackman, and B. C. L. Weedon. 1959. Stereochemistry and synthesis of phytol, geraniol and nerol. Proc. Chem. Soc. 263.

19. Crabbe, P., C. Djerassi, E. J. Eisenbraun, and S. Liu. 1959. Optical rotary dispersion studies. XXIX. Absolute configuration of phytol. Proc. Chem. Soc. 264.
20. Kates, M., C. N. Joo, B. Palameta, and T. Shier. 1967. Absolute sterochemical configuration of phytanyl (dihydrophytyl) groups in lipids of Halobacterium cutirubrum. Biochemistry. 6: 3329.

21. Klebe, J. F., H. Finkbeiner, and D. M. White. 1966. Silylations with bis (trimethylsilyl) acetamide, a highly reactive silyl donor. J. Amer. Chem. Soc. 88: 3390.

22. Ashenhurst, E. M., J. H. D. Millar, and T. G. Milliken. 1958. Refsum's syndrome affecting a brother and two sisters. Brit. Med. J. 2: 415.

23. Bonduelle, M., P. Bouygues, G. Lormeau, G. DeLoux, P. Laudat, and L. M. Wolf. 1966. Maladie de Refsumetude des lipides du serum et des urines. Rev. Neurol. Paris. 115: 933.

24. Uhlendorf, B. W., A. I. Holtz, M. B. Mock, D. S. Fredrickson. 1966. Persistence of a metabolic defect in tissue cultures derived from patients with NiemannPick disease. In Inborn Disorders of Sphingolipid Metabolism. S. M. Aronson and B. W. Volk, editors. Pergamon Press Inc., New York. 443.

25. Eagle, H. 1959. Amino acid metabolism in mammalian cell cultures. Science. 130: 432.

26. Dulbecco, R., and M. Vogt. 1954. Plaque formation and isolation of pure lines with poliomyelitis viruses. J. Exp. Med. 99: 167.

27. Lowry, O. H., N. J. Rosebrough, A. L. Farr, and R. J. Randall. 1951. Protein measurement with the folin phenol reagent. J. Biol. Chem. 193: 265.

28. Steinberg, D. 1960 . A new approach to radioassay of aqueous solutions in the liquid scintillation spectrometer. Anal. Biochem. 1: 23.

29. Butler, F. E. 1961. Determination of tritium in water and urine; liquid scintillation counting and rate-of-drift determination. Anal. Chem. 33: 409.

30. Borgström, B. 1952. Investigation on lipid separation methods: separation of phospholipids from neutral fat and fatty acids. Acta Physiol. Scand. 25: 101.

31. Spector, A. A., and D. Steinberg. 1966. Relationship between fatty acid and glucose utilization in Ehrlich ascites tumor cells. J. Lipid Res. 7: 657.

32. Ryser, H. J. P. 1963. The measurement of Isi-serum albumin uptake by tumor cells in tissue culture. Lab. Invest. 12: 1009.

33. Eagle, H., and K. A. Piez. 1960. The utilization of proteins by cultured human cells. J. Biol. Chem. 235: 1095.

34. Dole, V. P. 1956. A relation between nonesterified fatty acids in plasma and the metabolism of glucose. J. Clin. Invest. 35: 150.

35. Steinberg, D., C. E. Mize, J. Avigan, H. M. Fales, L. Eldjarn, K. Try, O. Stokke, and S. Refsum. 1967. Studies on the metabolic error in Refsum's disease. J. Clin. Invest. 46: 313.

36. Mize, C. E., J. H. Herndon, Jr., J. P. Blass, G. W. A. Milne, C. Follansbee, P. Laudat, and D. Steinberg. 1968. Localization of the oxidative defect in phytanic acid degradation in patients with Refsum's disease. J. Clin. Invest. 48: 1033.

37. Hansen, R. P., F. B. Shorland, and I. A. M. Prior. 1966. The fate of phytanic acid when administered to rats. Biochim. Biophys. Acta. 116: 178.

38. Hansen, R. P., F. B. Shorland, and I. A. M. Prior. 1968. The occurrence of 4,8,12-trimethyltridecanoic acid in the tissues of rats fed high levels of phytanic acid. Biochim. Biophys. Acta. 152: 642.

39. Eldjarn, L. 1965. Heredopathia atactica polyneuritiformis (Refsum's disease)-a defect in the omega-oxi- 
dation mechanism of fatty acids. Scand. J. Clin. Lab. Invest. $17: 178$.

40. Eldjarn, L., K. Try, and O. Stokke. 1966. The ability of patients with heredopathia atactica polyneuritiformis to omega-oxidize and degrade several isoprenoid branchchained fatty structures. Scand. J. Clin. Lab. Invest. 18: 141.

41. Try, K., and L. Eldjarn. 1967. Normalization of the tricaprin test for omega-oxidation in Refsum's disease upon lowering of serum phytanic acid. Scand. J. Clin. Lab. Invest. 20: 294.

42. Eldjarn, L., O. Stokke, and K. Try. 1966. Alpha-oxidation of branched-chain fatty acids in man and its failure in patients with Refsum's disease showing phytanic acid accumulation. Scand. J. Clin. Lab. Invest. 18: 694.

43. Antony, G. J., and B. R. Landau. 1968. Relative contributions of alpha, beta and omega-oxidative pathways to in vitro fatty acid oxidation in rat liver. J. Lipid Res. 9: 267.

44. Seubert, W., and U. Remberger. 1963. Untersuchungen über den bakteriellen Abbau von Isoprenoiden. II. Die Rolle der Kohlensäure. Biochem Z. 338: 245.

45. Eldjarn, L., K. Try, and O. Stokke. 1966. The existence of an alternative pathway for the degradation of branch-chained (sic) fatty acids, and its failure in heredopathia atactica polyneuritiformis (Refsum's disease). Biochim. Biophys. Acta. 116: 395.

46. Stokke, O., K. Try, and L. Eldjarn. 1967. $\alpha$-Oxidation as an alternative pathway for degradation of branchedchain fatty acids in man and its failure in patients with Refsum's disease. Biochim. Biophys. Acta. 144: 271.

47. Stokke, O. 1968. Alpha-oxidation of a beta-methyl substituted fatty acid in guinea pig liver mitochondria. Biochim. Biophys. Acta. 152: 213.

48. Try, K. 1967. Indications of only a partial defect in the alpha-oxidation mechanism in Refsum's disease. Scand. J. Clin. Lab. Invest. 20: 255.

49. Eldjarn, L., K. Try, O. Stokke, A. W. Munthe-Kaas, S. Refsum, D. Steinberg, J. Avigan, and C. E. Mize. 1966. Dietary effects on serum phytanic acid levels and on clinical manifestations in heredopathia atactica polyneuritiformis. Lancet. 1: 691 .

50. Tsai, S-C., J. Avigan, and D. Steinberg. 1969. Studies on the alpha-oxidation of phytanic acid by rat liver mitochondria. J. Biol. Chem. In press.
51. Laurell, S. 1968. The action of lipoprotein lipase on glyceryl triphytanate. Biochem. Biophys. Acta. 152: 80.

52. O'Brien, J. S. 1967. Cell membranes-composition: structure: function. J. Theor. Biol. 15: 307.

53. Steinberg, D., J. Avigan, C. E. Mize, J. H. Baxter, J. Cammermeyer, H. M. Fales, and P. F. Highet. 1966. Effects of dietary phytol and phytanic acid in animals. J. Lipid Res. 7: 684.

54. Stokke, O. 1967. Alpha-oxidation of fatty acids in various mammals and a phytanic acid feeding experiment in an animal with a low alpha-oxidation capacity. Scand. J. Clin. Lab. Invest. 20: 305.

55. Richterich, R., P. Van Mechelen, and E. Rossi. 1965. Refsum's Disease (heredopathia atactica polyneuritiformis) : an inborn error of lipid metabolism with storage of 3,7,11,15-tetramethylhexadecanoic acid. Amer. J. Med. 39: 230.

56. Nordhagen, E., and J. Grondahl. 1964: Heredopathia atactica polyneuritiformis (Refsum's disease). Acta Ophthalmol. $42: 629$.

57. Hajra, A. K., and N. S. Radin. 1963. Isotopic studies of the biosynthesis of the cerebroside fatty acids in rats. J. Lipid Res. 4: 270.

58. Levis, G. M., and J. F. Mead. 1964. An alpha-hydroxy acid decarboxylase in brain microsomes. J. Biol. Chem. 239: 77.

59. McDonald, R. C., and J. F. Mead. 1968. The alphaoxidation system of brain microsomes: cofactors for alpha-hydroxy acid decarboxylation. Lipids. 3: 275.

60. Tsai, S-C., J. Avigan, and D. Steinberg. 1968. The pathway for mitochondrial oxidation of phytanic acid (3,7,11,15-tetramethylhexadecanoic acid). Fed. Proc. 27 : 648. (Abstr.)

61. Bowen, D. M., and N. S. Radin. 1968. Hydroxy fatty acid metabolism in brain. In Advances in Lipid Research. R. Paoletti and D. Kritchevsky, editors. Academic Press Inc., New York. 6: 255.

62. MacBrinn, M. C., and J. S. O'Brien. 1968. Lipid composition of the nervous system in Refsum's disease. J. Lipid Res. 9: 552.

63. Kolodny, E. H., W. K. Hass, B. Lane, and W. D. Drucker. 1965. Refsum's syndrome: report of a case including electron microscopic studies of the liver. Arch. Neurol. 12: 583. 